\title{
Cross-cultural Analysis of Main Economic Partners of the Republic of Moldova
}

\author{
Angela PIRLOG ${ }^{1}$
}

\begin{abstract}
The paper represents a comparative study of national culture features of the main commercial partners of the Republic of Moldova and the countries preferred by Moldovan citizens to emigrate: Romania, Russia, Italy and Germany. The research focused on two cultural bipolar models: Hofstede, which comprises six cultural dimensions: individualism vs. collectivism, power distance, uncertainty avoidance, masculinity vs. femininity, long-term vs. short-term orientation, indulgence vs. restraint, and Trompenaars-Hampden-Turner, which contains seven dimensions: universalism vs. particularism, individualism vs. communitarianism, neutral vs. emotional, specific vs. diffuse, achievement vs. ascription, sequential time vs. synchronous time, internal vs. external control. The established similarities and differences, knowledge of cultural specificity in international interactions, both social and economic, is an added value for individuals to successfully integrate and fit into a society, other than their native, and for businesses to be successfully managed on international level.
\end{abstract}

Keywords: Hofstede, Trompenaars and Hampden-Turner, cultural dimensions, migration, intercultural interaction, countries

JEL code: F22, M14, O57, Z13

\section{Introduction}

The contemporary social and business environment, characterized by a high degree of globalization and cultural diversity, emphasizes the importance of developing a better understanding of intercultural interaction

\footnotetext{
${ }^{1}$ Angela PIRLOG is university lecturer of Academy of Economic Studies of Moldova, Chisinau, Republic of Moldova. https://orcid.org/0000-0003-1137-1555 E-mail: angela.pirlog@ase.md
} 
that occurs during contacts between entities and people from different cultures.

Recently, due to the independence (Declaration of Independence of the Republic of Moldova, 2021) and openness of the Republic of Moldova to the outside world, contacts of any type and at any level, have developed. The citizens of the Republic had the opportunity to travel freely, to work abroad, foreign businessmen started to invest in the Republic of Moldova, domestic enterprises were more open to export.

The most valuable connectors with the global environment and economy are the free movement of people, foreign direct investments and foreign trade. They are the essential links of the national economy of the Republic of Moldova to the world economic space, by offering individuals and companies from our country opportunities to integrate and develop on international social and economic level.

In order to analyse and evaluate the similarities and differences of national cultures of the main Republic of Moldova's economic partners along with the preferred by Moldovans countries in order to immigrate, it is certainly necessary to use specific models to examine the values of these cultures. The models proposed by various specialists (Hofstede, Hofstede \& Minkov M, 2010; Trompenaars \& Hampden-Turner, 2020) in this area of research are not all-encompassing and are not mutually exclusive. Each approach presents different perspectives and can be useful separately or in combination with others.

We consider that important countries for our scientific approach are: Romania having the common shared history during centuries and partner number one in bilateral commercial relations; Russia, due to its influence, economic, but especially culturally, on the cultural group of the Balkan countries, of which our country is part, and, also, having a big number of emigrants from the Republic of Moldova; Italy is still a top country preferred by Moldovans to emigrate and also having considerable impact on commercial relations with the Republic of Moldova; Germany, also placed in the top of commercial partners of our country. 


\section{Literature review}

The analysis of the literature related to the researched and described in this article subject shows that multiple attempts have been made to study the cultural dimensions in various countries. Different researchers have worked on discovering, analysing and offering practical advice how effectively interact in different cultural environments. Several authors have used this approach, from the study of Kluckhohn \& Stroedbeck (1961) to the contribution of Geert Hofstede (2001), his team (Hofstede, Hofstede \& Minkov, 2010) and the works of Trompenaars \& Hampden-Turner (2020), the GLOBE project (House et al, 2004). The Dutch psychologist Geert Hofstede is one of the researchers, who has dedicated his entire academic career analysing behavioural patterns of various cultures and their impact on quality of life in over 50 countries around the world. His research starts with the statement: all modern or traditional societies face the same fundamental problems - only the answers differ, respectively they can be subjected to a comparative cross-cultural study (Popov, 2019, p.4).

Trompenaars and Hampden-Turner states in "Riding the Waves of Culture" (Trompenaars \& Hampden-Turner, 2020) that each culture has its own specific solutions to universal problems. In their surveys, they presented a series of dilemmas to respondents and asked them to choose one of a given solutions. In his way they established the respondents' cultural inclination.

In Moldova the importance of national and organizational cultural similarities and differences due to their impact on the processes of communication, negotiation and management were studied by national researchers (Covaș \& Pirlog, 2017; Tâu \& Ibrahim Mustafa Sharfeldin, 2017).

Cultural values dictate manners that people from the Republic of Moldova use to interact with representatives of other countries, thus affecting international business development that influence approaches that individuals use to perform certain tasks (Tâu \& Ibrahim Mustafa Sharfeldin, 2017).

\section{Data and Methodology}

The positive dynamics of foreign trade of enterprises in the Republic of Moldova proves that the need for interaction with representatives of 
companies in other countries is constantly growing. Figures 1 and 2 show which countries have the closest economic contact with it.

Exports from the Republic of Moldova (figure 2.) with a much lower due to objective causes, such as: economic recession and trade barriers imposed by Russia, light economic growth in the EU, high international quality standards, pandemic crisis COVID 19.

\section{Figure 1. The Volume of Imports to the Republic of Moldova (main commercial partners)}

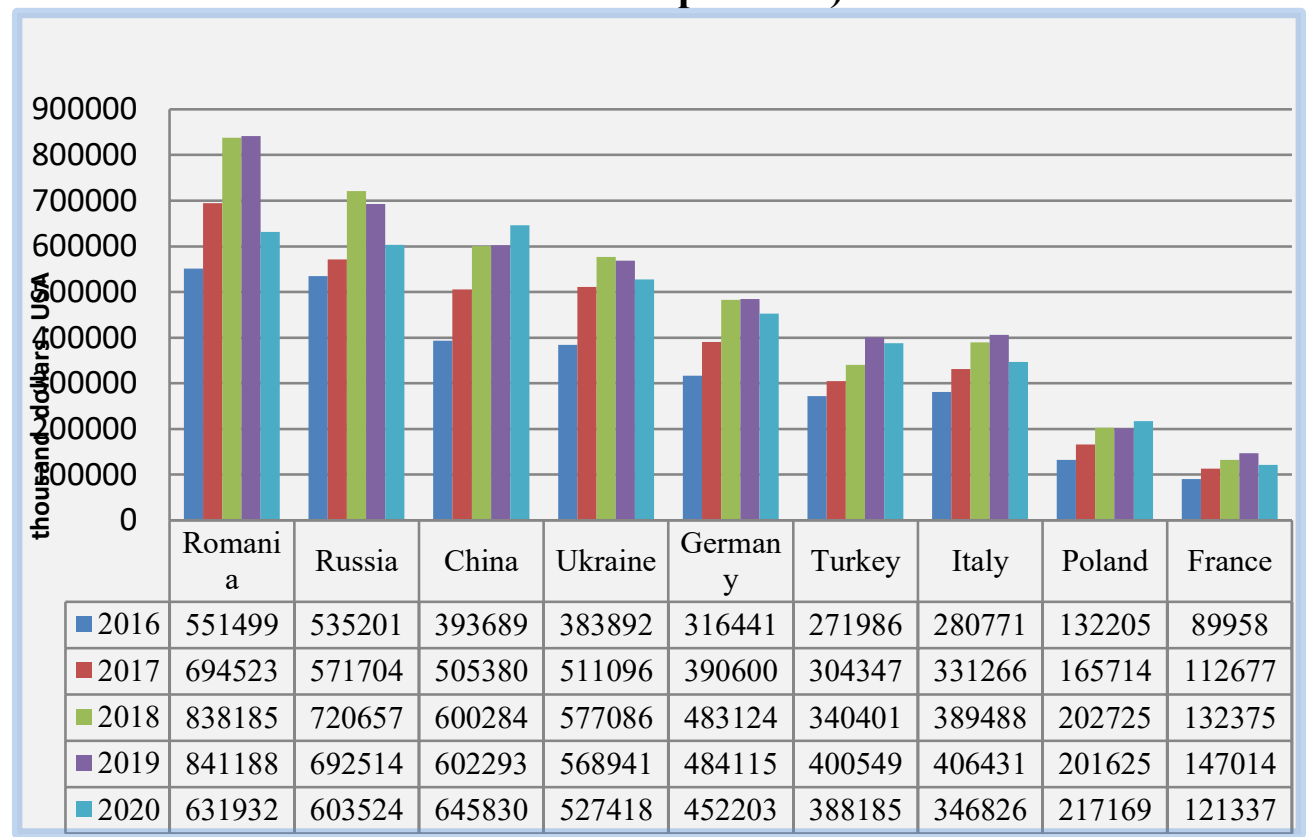

Source: Elaborated by author based on (Annual time series. International trade,2021 [visited on 10.06.2021]

According to the Ministry of Internal Affairs of the Republic of Moldova and Office of Migration and Asylum (2018) the phenomenon of migration in the Republic of Moldova is characterized by the international emigration of Moldovan citizens, less by the immigration of foreigners. Studies in the field of migration (Extended Migration Profile, 2018) show that the main share of Moldovan migrants remains emigration for economic purposes, especially due to low level of income in our country.

However, in recent years, among other causes of migration are the academic ones (the tendency to obtain internationally recognized studies, which would ensure a successful job) and family reunification. 
By 2014-2015 about 2/3 of the emigrant population, estimated at up to one million people, was established Russian Federation but in recent years Moldovan citizens have moved to other countries, preferring European countries.

The Ministry of Internal Affairs of the Republic of Moldova, Office of Migration and Asylum (2018) specifies in the same survey that at the end of $2018,42 \%$ of migrants were in the Russian Federation, over 23\% in Italy, 7\% in the US, 3\% in Ukraine, Canada, Germany, Spain and Israel.

Figure 2. The Volume of exports from Republic of Moldova (main commercial partners)

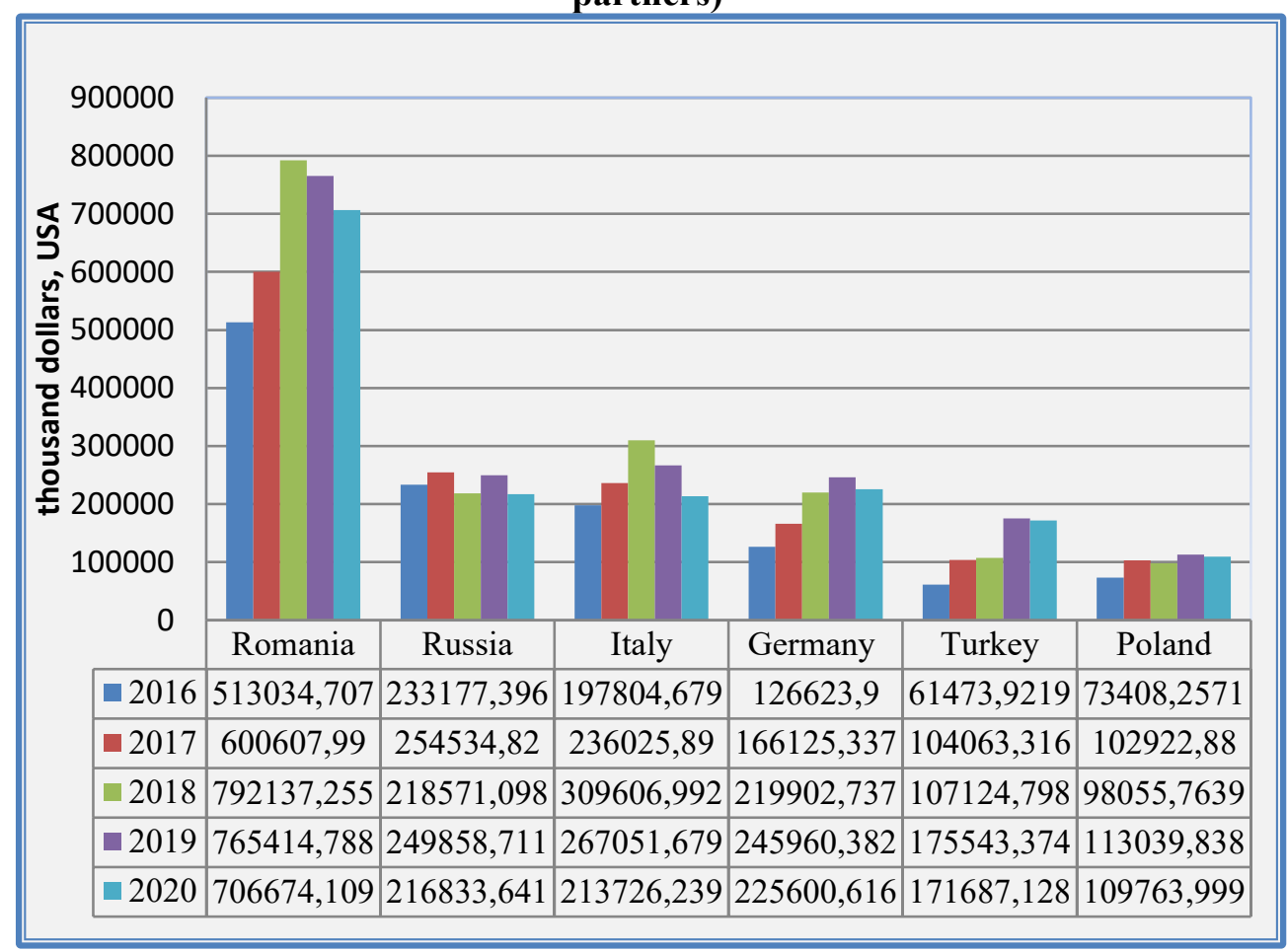

Source: Elaborated by author based on (Annual time series. International trade,2021) [visited on 10.06.2021]

According to data of Government of Romania (2021), the number of Moldovan citizens who have Romanian citizenship has significantly increased in the last 20 years and today reached 642,149 people out of a de facto population of about 2.7 million inhabitants, which means that one in four Moldovans has Romanian citizenship. 
People, in order to be effective in contacts with representatives of other cultures, should be aware of the thing that an intercultural approach of social and economic relations is necessary, either in business or in other types of relationship. Relationships between people, organizations, companies, institutions, states, regional bodies, etc. involve the interference and interaction of different cultures. Thus, an individual or an enterprise is defined by a set of core values that represent his/her or its "cultural profile". In social and business relationships, people and organizations from different countries come into contact with each other, so that the interaction takes place in an environment characterized by cultural diversity.

For the present research, that is a comparative analysis of six cultural dimensions according to Hofstede model, based on the official information from Hofstede Insights (2021b, 2021c, 2021d, 2021e, 2021f) and seven dimensions according to Trompenaars-Hampden-Turner (2020) described in the latest edition of "Riding the Waves of Culture: Understanding Diversity in Global Business" of main economic partners of the Republic of Moldova that can be seen in figures 1 and 2 .

Hofstede and his colleagues distinguished six cultural:

1. Power Distance Index (PDA) shows the level of inequity and the relationship with authority.

2. Individualism versus collectivism (IDV) is the relationship between individual and group. Individualism is characteristic of societies, in which the connections between individuals are distant: everyone is expected to take care of themselves or take care of their own family. Collectivism is specific for societies, which integrates people into strong subgroups, protects them for making them loyal.

3. Masculinity versus Femininity (MAS) determines the social implications of masculine and feminine characteristics. Masculinity encourage competition, assertiveness, definition of social roles of sexes, and femininity is specific for societies where the social roles of the sexes overlap, the main characteristics are modesty, sensitivity and concern about quality of life.

4. Uncertainty control or avoidance (UAI) is the way how the uncertainty is treated, regarding aggression control and expression of emotions. Uncertainty control indicates the extent to which members 
of a culture feel threatened by unclear or unknown situations and the level at which they are open and prepared for them.

5. Long-term orientation versus Short-term orientation (LTO) determines the way to solve a short-term or long-term issue. In a long-term oriented society, time is perceived as a vector, and people tend to look to the future more than to be interested in the present or to remember the past. Short-term cultures appreciate traditional methods, spend a lot of time developing relationships, and generally view time as a circle. This means that the future and past events are interconnected, and "what cannot be done today can be done tomorrow".

6. Indulgence versus Restraint (IVR) determines the freedom of the individual in relation to cultural norms, shows the ability of a culture to meet the immediate needs and personal desires of the society members. In indulgent societies the satisfaction and happiness are encouraged. Where restraint is a value, strict rules and social norms prevail and personal desires are inhibited.

Fons Trompenaars and Charles Hampden-Turner distinguished seven dimensions of national culture:

1. Universalism Versus Particularism is the dimension about rules and relationships. Universalism is the situation in which people focus more on rules, laws and values. Particularism is the situation people believe that the circumstances and relationships they are in determine the rules they live by.

2. Individualism Versus Communitarianism is about what prevails: individual or the group. Individualism states that team members believe in personal freedom and achievements. They prefer to make and be responsible for their own decisions and take care of themselves Communitarianism is the tendency where group is more important than the individual.

3. Specific versus Diffuse is the dimension that outlines how much people are involved and delimitation of public and personal life.

4. Neutral versus Emotional is all about how people express their emotions: neutral are determined by strong emotional intelligence and the reason influences their actions. Emotional individuals are active to express their feelings and emotions. 
5. Achievement versus Ascription determines how people concept the attribution of status. People with achievement rely on value performance, regardless of their position in the society or organization. The mentality "you are what you do" is the most important. Ascription inclination of a society means that power, titles and position are the most important in defining people's behaviour and status.

6. People manage time differently. Thus, the dimension Sequential Time versus Synchronous Time shows the way they perceive it. People who are oriented to sequential time like to have things happen in a logical, sequential order. They are punctual, like to plan and stay on schedule. Those who prefer synchronous time, recognize the present and the future as the same period of time. They view plans, deadlines and commitments as moveable segments.

7. Internal Direction versus Outer Direction involves the way people view their environment. If people within a society have internal direction, they believe they can control their environment in order to achieve their goals. Individuals using outer direction think that events, happening with and around them, influence and control them. They focus their attention on others and avoid conflict as much as possible.

\section{The Model and Findings}

In the figures below (figure 3 and 4) we present the comparative study of the cultural dimensions of four countries: Romania, Russia, Germany, Italy, countries with which the Republic of Moldova has the most intense economic and trade exchanges and also preferred by Moldovans for emigration.

As we can see in the figure 3, the obtained high score of Distance to power (PDI) for Russia (93) and Romania (90), as expected, proves the fact that they shared a common communist past. Work relationships between high-level employee and their subordinates are distant. The boss is an authoritarian figure and the main decision-maker in the majority of cases. Very rarely do employees dare to contradict their superiors and the employees have to obey.

Germany (35) and Italy (50) present a low to medium level of power distance. It means that hierarchy in society and organizations has a 
conventional distribution of roles and a basic characteristic is decentralization. The specific type of leadership is that democratic.

\section{Figure 3. Cultural dimensions of the main economic partners of the Republic of Moldova (according Hofstede model)}

\begin{tabular}{|c|c|c|c|c|c|c|}
\hline 100 & & & & & & \\
\hline 90 & & & & & & \\
\hline 80 & & & & & & \\
\hline 70 & & & & & & \\
\hline 60 & & & & & & \\
\hline 50 & & & & & & \\
\hline 40 & & & & & & \\
\hline 30 & & & & & & \\
\hline 20 & & & & & & \\
\hline 10 & & & & & & \\
\hline$\overbrace{}^{\circ} 0$ & PDI & IDV & MAS & UAI & LTO & IVR \\
\hline Rep. Moldova & 90 & 27 & 39 & 95 & 71 & 19 \\
\hline Romania & 90 & 30 & 42 & 90 & 52 & 20 \\
\hline Russia & 93 & 39 & 36 & 95 & 81 & 20 \\
\hline Germany & 35 & 67 & 66 & 65 & 83 & 40 \\
\hline Italy & 50 & 76 & 70 & 75 & 61 & 30 \\
\hline
\end{tabular}

Source: Elaborated by author based on (Pirlog, 2020; Hofstede Insights, 2021) visited on [15.06.2021]

In the countries where the level of the Individualism / Collectivism (IDV) is low as it is in the Republic of Moldova (27), are countries where the relationship prevails over goals. People prefer to keep friendships at work and outside it, rather than set the professional goal that can threaten the relationship. We noticed, that Romania (30) and Russia (39) are not very far from Moldova's score. In these countries the government has a dominant role in their economic systems. Society expects the government to solve and manage the entire economic system and the economic changes to come from government structures rather than from themselves. Justice is selective depending on those with power and influence. Corruption is flourishing, being one of the conditions for slow development. 
At the far pole are Germany and Italy. They present high level of individualism that means individual performance, personal freedom and independence are valued the most. Also, laws and rights are supposed to be the same for everyone.

The score for Masculinity/Femininity (MAS) in the Republic of Moldova (39), neighbouring countries: Romania (42) and Russia (36) indicate that the societies have characteristics of feminine cultures. These cultures are characterized by gentle behaviour, compromise, conflict avoidance. In feminine societies, work has the role of obtaining a minimum comfort for existence.

Far from above mentioned countries, with a high index of masculinity, we can see Germany (66) and Italy (70). In these countries, specific male characteristics: competition, power struggle, knowledge and recognition prevail. In masculine cultures, conflict is solved through confrontation ending with the victory of the strongest and working means economic development, productivity and performance.

Moldova is in the top of the negative ranking of Uncertainty avoidance (EVI), having the index 101. Not far are Russia (95), Romania (90). High level of stress and anxiety, excessive concern for the unknown are main indicators of these cultures. Stress in everyday life, at home and at work. Anxiety is a diffuse state of concern about what can happen. The uncertainty of life is seen as a threat for people. Reforms, professional, economic, social and political changes, innovations are avoided. What is different is considered dangerous, being preferred already known practices, even they are dysfunctional. Bureaucracy and control characterized by strict rules have the role to prevent uncertainties and changes. People prefer to keep their jobs stable, to the detriment of unsatisfactory working conditions or a toxic organizational environment and a low salary. (Popov et al, 2020)

Germany (65) and Italy (75) define their societies with a low level of uncertainty and ambiguity acceptance. People in these countries are open to what is new, different and try to implement new social and technological practices. The phenomenon of encouraging innovative changes in society and work lead to development of companies and institutions

The score obtained by the Republic of Moldova (36) for time orientation (OTL) means that the thinking and planning of our society is short-term oriented. 
We have noticed that Romania (52) and Italy (61) are above the average score and quite highly placed are Russia (81) and Germany (83).

In short-term oriented cultures the results of the efforts made, opening or investing in a business, achieving goals are expected as fast as possible. The financial resources are invested in real estate, expensive cars or clothes. The country's economic growth is slow because there is no money for longterm investment (Popov et al, 2020).

In countries with long-term orientation financial resources are invested in business, personal investment or education, which could have positive longterm consequences. More important are the long-term profits, over 5-10 years.

Table 1. National cultural profile in the Republic of Moldova according to the Trompenaars-Hampden-Turner cultural model

\begin{tabular}{ll}
\hline \multicolumn{2}{|l}{ Cultural Dimensions in the Republic of according Trompenaars-Hampden-Turner } \\
\hline $\begin{array}{l}\text { Individualism } \\
\text { Medium level }\end{array}$ & $\begin{array}{l}\text { Communitarism/collectivism } \\
\text { Medium level }\end{array}$ \\
\hline $\begin{array}{l}\text { Universalism } \\
\text { Low level }\end{array}$ & $\begin{array}{l}\text { Particularism } \\
\text { High level }\end{array}$ \\
\hline $\begin{array}{l}\text { Specificity } \\
\text { Decreasing average level }\end{array}$ & $\begin{array}{l}\text { Diffuseness } \\
\text { Growing average level }\end{array}$ \\
\hline $\begin{array}{l}\text { Attribution } \\
\text { Medium level }\end{array}$ & $\begin{array}{l}\text { Ascription } \\
\text { Medium level }\end{array}$ \\
\hline $\begin{array}{l}\text { Inner Direction } \\
\text { Growing average level (young } \\
\text { generation) }\end{array}$ & $\begin{array}{l}\text { Outer Direction } \\
\text { Decreasing average level (older generation) }\end{array}$ \\
\hline $\begin{array}{l}\text { Affectivity } \\
\text { Decreasing average level }\end{array}$ & $\begin{array}{l}\text { Neutrality } \\
\text { Growing average level }\end{array}$ \\
\hline $\begin{array}{l}\text { sequential time } \\
\text { Growing average level (older } \\
\text { generation) }\end{array}$ & $\begin{array}{l}\text { Synchronous time } \\
\text { Growing average level (young } \\
\text { generation) }\end{array}$ \\
\hline
\end{tabular}

Source: Elaborated by the author based on (Pirlog, 2017; Trompenaars \& Hampden-Turner, 2020)

By the score of Indulgence (IVR) in Moldova (19) proves that it is low and is a characteristic if an austere culture. We note that restraint is also specific for Romania and Russia (20). In general, this trend is observed in former communist countries or other authoritarian regimes. Freedom of expression is discouraged and the expression of personality is a difficulty 
(Popov et al, 2020). Members of society, including the organizational framework, are afraid of criticism and others' opinion. Cultural restraints inhibit the development of personality and the realization of his/her own desires, people become tense, stressed and nervous.

Germany (40) has a high degree of permissiveness and individual freedom but still under the medium level. This is felt in everyday social interactions where citizens show happiness, optimism and kindness.

Another model that we used to characterize the national cultures of analysed countries is that of Fon Trompenaars and Charles Hampden-Turner.

Information from Table 1, containing characteristics of national culture in the Republic of Moldova established by Pirlog (2017) and figure 6, displaying the scores of countries in our study established by Trompenaars \& Hampden-Turner (2020), will help to make a comparison of these cultures according Trompenaars-Hampden-Turner model.

\section{Figure 6. Cultural dimensions of the main commercial partners of the Republic of Moldova (according to the Trompenaars-Hampden-Turner model)}

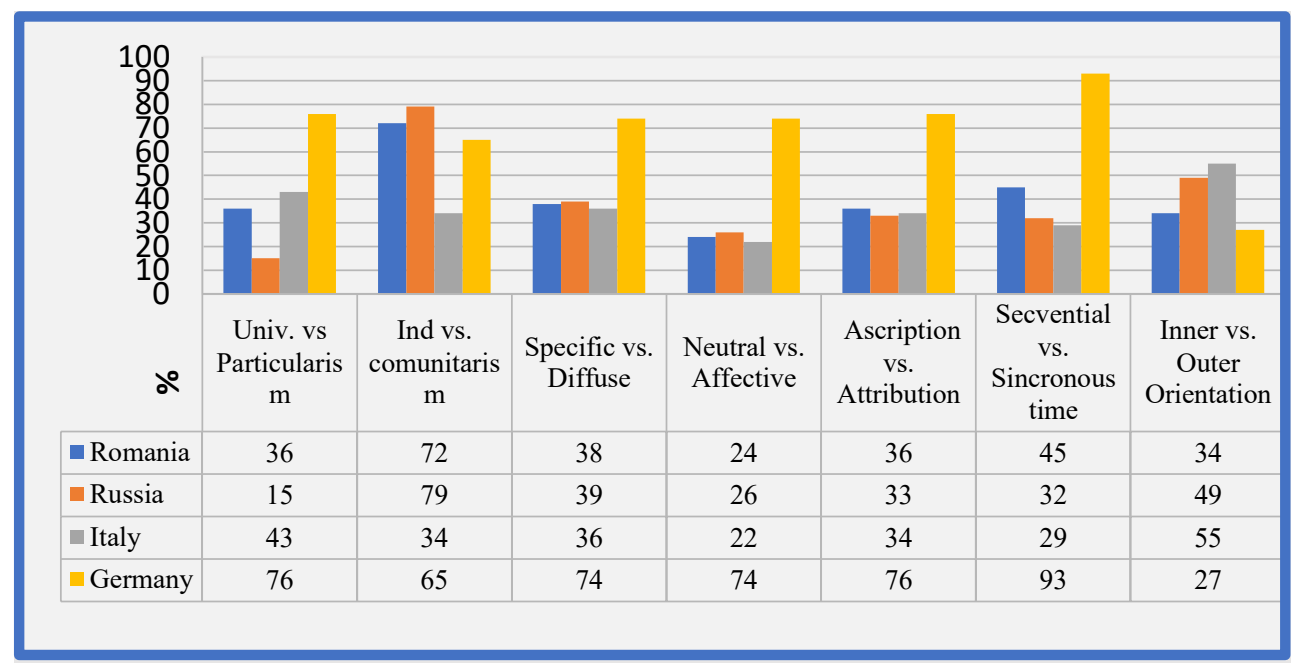

Source: Elaborated by author based on (Trompenaars \& Hampden-Turner, 2020)

Particularistic societies in our study are Romania, Russia and Italy. The same tendency is seen in the Republic of Moldova. It means that the emphasis is made on relationships and not on rules. There are several truths because 
people respect and take into consideration each other opinions. In business success, relationships have the main role.

Germany is considered a universalist country. It means that the emphasis is made more on rules and not on relationships and there is always just one truth of a specific situation. The contracts are the only framework for all business activity and interaction.

Diffuse trend countries are: the Republic of Moldova, Romania, Russia, and Italy, where people's personal and professional lives overlap, and believe that having good personal connections with their business partners is an essential condition for success. There is no clear limitation of workplace relationships and other types of social relationships.

Specific-oriented culture is that of Germany. People there believe that their professional life should remain separate from personal and their aspects must be kept distinctive from each other. Interactions between people are very well defined. People in such a culture believe that they can work very well together without necessarily having a good personal relationship.

Germany is country with a high score of individualism. Surprisingly individualistic societies are considered Romania and Russia. Probably, it is the case of horizontal individualistic cultures (eg. Sweden, Norway) people are expected to act as individuals and at the same time not be different from others (Triandis, 1995). The status of individuals, work and individual results are of great importance in these countries (Hofstede, Hofstede \& Mincov, 2010; House et al, 2004).

In collectivist cultures, like that of Italy in our study, the group and adherence to it matter the most because security and help is offered in exchange for individual loyalty. Belonging to a group is valued more than personal freedom and independence.

The most neutral society in our study is that of Germany. Germans do not show what they are and think, emotions are reflected only occasionally. Communication could be considered monotonous, almost boring.

Romania, Russia and Italy are countries with high level of emotional inclination. Individuals externalize their feelings and thoughts (verbal and nonverbal) without reservation or self-control. Communication is active, declamatory and dramatic. 
The Republic of Moldova score demonstrates a medium level of this dimension with neutral tendency. It means it contains characteristics of both, but more of to be neutral.

The country in our research with ascription tendency, is Germany. Social discrimination is insignificant there. Immigrants can integrate quite well into German society, women and men have the same rights, and sexual minorities are not disadvantaged. The position in the hierarchy does not take into account age, but knowledge and experience. Employment and wages are based on proven knowledge and skills, not diplomas other or less relevant papers. Hierarchical or professional advancement and dismissal depend on performance.

Attribution of status is specific to other representatives in our study: Romania, Russia, and Italy. Usually, elderly people (considered more experienced) are managers here, with high education degree, from the majority ethnic group and, most frequently, from higher social strata. Diplomas are very important when hiring. Hierarchical or professional promotion is slow and depend on age or seniority. In interpersonal relations, politeness and respect for the elderly, graduates of prestigious universities, doctors, etc. are very important.

Germany has a sequential perception of time. It means that rigorous planning of activities, random actions, etc. are treated with circumspection or disapproval; efficiency in carrying out activities or tasks, repeated delays are perceived negatively. Non-punctuality in business relations, delays, noncompliance with deadlines are interpreted as lack of interest in business. Perseverance and consistency in achieving goals are important as key features. Only one action is undertaken in a certain period of time and this must be completed before undertaking a new action.

At the opposite pole we can see the Republic of Moldova, Romania, Russia and Italy with synchronous perception of time. Their national cultures are characterized by: the development of events or activities that is determined rather by the urgencies; the development of interpersonal relationships have a great importance; satisfaction of all involved parties, respect of the partner "image".

Due to the information in this article we can analyse the Cultural Adaptability Profile (CAP) (Hofstede insights, 2021a) or other characteristics using specific tools (Trompenaars \& Hampden-Turner, 2021) to assess and 
predict how a person or management will react and cope with an intercultural situation and/or in an intercultural environment in order to maximize the chance of a successful insertion and collaboration. This reaction depends on a wide range of factors. One of them is the interaction between the personalities and their cultural values.

\section{Conclusions}

National culture represents a nucleus of resistance and protection against any form of external interference. Cultural aspects play a major role in the gradual establishment of relationship between people, relationship based either on mistrust and hostility, or on trust and openness.

Assessing and exchanging data on the national culture specific to countries preferred by migrants from the Republic of Moldova, as well as businessmen who want to internationalize their business, constitutes an added opportunity to develop cooperation mechanisms about estimating, analysing, avoiding intercultural risks and successful cooperation of representatives from analysed countries.

The knowledge of the national cultural characteristics in the Republic of Moldova and of main commercial partners and countries preferred by Moldovans for migration, examined in the present research, would facilitate the successful integration and management in different cultural environment, of the diverse workforce within the international enterprises and projects both in the country and abroad. Thus, we demonstrated the usefulness of knowing the properties of the "cultural profile" in the Republic of Moldova that could be effective for quantifying the cultural values of society members in terms of 13 dimensions, Hofstede (6) and Trompenaars-Hampden-Turner (7). Likewise, our model of the national cultural profile will help us to understand, manage and transform culture, hopefully, without losing our identity.

In this context, we could build an "appropriate model" suggested for intercultural interaction of individuals and management, as well as for methods for developing intercultural competence and transfer of managerial techniques and know-how according to the cultural profile of the Republic of Moldova and countries analysed in this paper.

Also, we would like to note that, in order to have a complete picture of attitudes and behaviours of people within any society, the characteristics 
of the national culture should be analysed along with other variables, such as: age, sex, marital or socio-economic status.

We hope that the research exposed in this paper will be useful to individuals, authorities and enterprises from the Republic of Moldova that have access to the international space in order to make the interaction mutually successful.

\section{References}

Covas, L., Pirlog, A. (2017). The Dimensions of Corporate and National Culture: The Cross-National Analysis. Economica, 3 (101), 17-27.

Presidency of the Republic of Moldova (2021, July 12). Declaration of Independence of the Republic of Moldova.

https://www.presedinte.md/eng/declaration

Government of Romania (2021, May). Cetatenie româna pentru basarabeni. https://cdn.g4media.ro/wp-content/uploads/2021/05/Cetatenieromana-pentru-basarabeni.pdf .

National Bureau of Statistics (NBS) (2020). Exporturile Republicii Moldova, structurate pe ţări şi grupe de tări (1997-2020), https://statbank.statistica.md/pxweb/pxweb/ro/40\%20Statistica $\% 20$ e conomica $/ 40 \% 20$ Statistica $\% 20$ economica_21\%20EXT_EXT010 serii\%20anuale/?rxid=b2ff27d7-0b96-43c9-934b-42e1a2a9a774 .

National Bureau of Statistics (NBS) (2021). International trade/ Comerţ exterior. Annual time series. https://statistica.gov.md/ category.php? $1=$ ro\&idc $=336$

Ministry of Internal Affairs of the Republic of Moldova, Office of Migration and Asylum, (2018). Extended Migration Profile in the Republic of Moldova. http://bma.gov.md/sites/default/files/media/ra_pme_20142018_0.pdf .

Hofstede, G. (2001). Culture's consequences: Comparing values, behaviors, institutions and organizations across nations (2nd ed.) Thousand Oaks CA: Sage.

Hofstede, G. _Hofstede G J , Minkov M. (2010). Cultures and Organizations: Software of the Mind (3rd Ed.). New York, NY: McGraw-Hill Education.

Hofstede Insights (2021a) The cultural adaptability profile (CAP). https://hi.hofstede-insights.com/cap.

Hofstede Insights. (2021b). What About Germany? https://www.hofstedeinsights.com/country-comparison/germany/. 
Hofstede Insights (2021c). What About Italy? https://www.hofstedeinsights.com/country-comparison/italy/.

Hofstede Insights (2021d). What About Moldova? https://www.hofstedeinsights.com/country-comparison/moldova/.

Hofstede Insights (2021e). What About Romania? https://www.hofstedeinsights.com/country-comparison/romania/

Hofstede Insights (2021f). What About Russia? https://www.hofstedeinsights.com/country-comparison/russia/

House, R.J., Hanges, P.J., Javidan, M., Dorfman P.W., Gupta V. (2004) Culture, Leadership, and Organizations: The GLOBE Study of 62 Societies, Thousand Oaks, CA: Sage.

Kluckhohn, F., Strodtbeck, F (1961) Variations in value orientation. Evanston, IL: Row, Peterson NY: Harper Collins.

Pirlog, A. (2020). Intercultural "Diagnosis" of Management in the Republic of Moldova According to Geert Hofstede Model: Comparative Analysis, CSIE Working Papers, 16, 119-128. https://csei.ase.md/wp/files/issue16/WP_Issue16_119-128_PIR.pdf

Pirlog, A. (2017) Analysis of the Dimensions of National Culture in the Republic of Moldova According to Fons' Trompenaars and Hampden-Turner's Model. Vol.1 The scientific symposium of young researchers. 15th ed.,161-165.

https://ibn.idsi.md/sites/default/files/imag_file/161-165.pdf

Popov, Ș., Mendes, T., Toma, C., Mihăila, A-M., Barbarov, I., Vozian, M., Gherghelegiu, S., Stavinschi, D. (2020) Analiza culturală și psihologică a societății din Republica Moldova (conform modelului teoretic a lui Geert Hofstede) Centrul de cercetare științifică în psihologie.https://www.researchgate.net/publication/338374501_An aliza_culturala_si_psihologica_a_societatii_din_Republica_Moldova _conform_modelului_teoretic_a_lui_Geert_Hofstede.

Țâu, N., Ibrahim Mustafa Sharfeldin, M. (2017). Human Environment and Cultural Influence on the Development of International Business. Eastern European Journal Of Regional Studies,3(2), 82-92. https://csei.ase.md/journal/files/issue_32/TAU_EEJRS_Vol_3_Issue 2.pdf.

Triandis, H. C. (1995). Individualism and collectivism. Boulder, CO: Westview Press.

Trompenaars, F., Hampden-Turner, C. (2020). Riding the Waves of Culture: Understanding Diversity in Global Business (4th Ed.). London: Nicholas Brealey Publishing.

Trompenaars, F., Hampden-Turner, C. (2021). Tools, https://www2.thtconsulting.com/tools/. 